\title{
Saline extract from Malpighia emarginata DC leaves showed higher polyphenol presence, antioxidant and antifungal activity and promoted cell proliferation in mice splenocytes.
}

\author{
BÁRBARA R.S. BARROS ${ }^{1}$, BRUNO RAFAEL BARBOZA ${ }^{1}$, BÁRBARA A. RAMOS ${ }^{2}$, MAIARA \\ C. DE MOURA ${ }^{2}$, LUANA C.B.B. COELHO ${ }^{2}$, THIAGO HENRIQUE NAPOLEÃ ${ }^{2}$, MARIA \\ TEREZA S. CORREIA ${ }^{2}$, PATRÍCIA MARIA G. PAIVA ${ }^{2}$, IRANILDO JOSÉ DA CRUZ FILHO ${ }^{1}$, \\ TÚLIO DIEGO DA SILVA ${ }^{3}$, CLÁUDIA S.A. LIMA ${ }^{4}$ and CRISTIANE M.L. DE MELO ${ }^{1}$
}

\author{
${ }^{1}$ Department of Antibiotics, Biosciences Centre, Federal University of Pernambuco, \\ Av. Prof. Artur de Sá, s/n, 50740-520 Recife, PE, Brazil \\ ${ }^{2}$ Department of Biochemistry, Biosciences Centre, Federal University of Pernambuco, \\ Av. Prof. Moraes Rego, 1235, 50670-901 Recife, PE, Brazil \\ ${ }^{3}$ Center for Strategic Technologies of the Northeast, Av. Prof. Luís Freire, 1, 50740-545 Recife, PE, Brazil \\ ${ }^{4}$ Department of Biophysics, Biosciences Centre, Federal University of Pernambuco, \\ Av. Prof. Moraes Rego, 1235, 50670-901 Recife, PE, Brazil
}

Manuscript received on April 19, 2018; accepted for publication on June 21, 2018

\begin{abstract}
How to cite: BARROS BRS, BARBOZA BR, RAMOS BA, MOURA MC, COELHO LCBB, NAPOLEÃO TH, CORREIA MTS, PAIVA PMG, CRUZ FILHO IJ, SILVA TD, LIMA CSAAND MELO CML. 2019. Saline extract from Malpighia emarginata DC leaves showed higher polyphenol presence, antioxidant and antifungal activity and promoted cell proliferation in mice splenocytes.. An Acad Bras Cienc 91: e20190916. DOI 10.1590/0001-3765201920180358.
\end{abstract}

\begin{abstract}
Currently, the research of new natural compounds with biological potential demonstrates great ethnopharmacological importance. In this study, we evaluated the biological properties promoted by saline extract from Malpighia emarginata DC leaves, whose objective is to evaluate the antioxidant, antimicrobial and cytotoxicity potential. Phytochemical characterization was performed by UPLC-MS chromatography to identify the chemical compounds. For the antioxidant potential, DPPH, ATT and FRAP methods were used. The antibacterial and antifungal tests were performed evaluating the MIC50, MIC90, CMB and CMF parameters. Moreover, antibiofilm action was evaluated. Cytotoxicity and proliferation were performed using splenocytes from Balb/c mice and were evaluated by cytometry. We found a list of phenolic compounds among other bioactive compounds in the $M$. emarginata saline extract. In addition, higher antioxidant profile and antifungal activity against different strains of Candida spp. was promoted by the saline extract. Splenocytes showed greater cell viability (more than $90 \%$ ) and showed higher proliferate index in 24 and 48 hours of incubation with the extract. Saline extract from Malpighia emarginata DC has potential action like antioxidant and antifungal agent without promote animal cell damage.
\end{abstract}

Key words: bioactive compounds, cytotoxicity, Malpighia emarginata DC, phytochemical.

\section{INTRODUCTION}

Human culture has been profoundly influenced by

Correspondence to: Cristiane Moutinho Lagos de Melo

E-mail: crismout_melo@hotmail.com

ORCID: 0000-0002-8831-0163 the diversity of plant species, particularly those used for therapeutic purposes. Currently, the continuous knowledge about the medicinal properties of plants has been the focus of several scientific investigations around the world. Is important and necessary the 
study of phytochemical constituents, therapeutic action mechanism and identify active principles responsible for many biological activities observed in medicinal plants (Lin et al. 2018). Moreover, many authors have been publishing evidences about the efficacy of medicinal plants and their constituents on the improvement of diseases as cancer (Shirzad et al. 2011), atherosclerosis (Asgari et al. 2012) and diabetes (Asgary et al. 2011).

Malpighia emarginata DC. is a plant found throughout Central and SouthAmerica. It is a tropical specie originating in the Caribbean region, being known as the Antillean cherry (Oliveira et al. 2012, Moreira et al. 2016). In Brazil the fruit is known as acerola and possess high content of ascorbic acid (vitamin C), carotenoids, anthocyanins, thiamine, riboflavin, niacin, proteins and mineral salts, mainly iron, calcium and phosphorous, being considered a functional food (Mezquita and Vigoa 2000, Rosso et al. 2008, Alvarez-Suarez et al. 2017). This plant also has other phytochemical constituents such as flavonoids, phenolic acids and polyphenols (Bataglion et al. 2015, Malegori et al. 2017). All these compounds are able to minimize oxidative damage caused by the reactive oxygen and nitrogen species in animal organism (Oliveira et al. 2012) and prevent some chronic diseases such as cancer (Mezadri et al. 2008, Leffa et al. 2014). Moreover, these molecules also exhibit potential therapeutic effect as anti-inflammatory, radiation-protective, chemoprotective, vasoprotective, inhibition of LDL oxidation and decrease the risks of cardiovascular diseases (Wang et al. 1997, Seeram and Nair 2002, Rosso et al. 2008).

Local communities, especially in northeast of Brazil, use the juice of acerola mainly for respiratory diseases as flu and bronchitis. However, some accounts showed that leaves of plant were used to make tea associated with garlic and honey to flu symptoms. In addition, recent biological studies have shown that acerola consuming is not dangerous to human cells.
Many researches show important biological actions promoted by different organic extracts (like phenolic and ethanolic fractions) made using leaves of M. emarginata (Silva 2014, Oliveira 2015, Rezende et al. 2018). However, is known that the true use of $M$. emarginata in local communities is like teas or infusions using water as the solvent.

Although the studies about $M$. emarginata fruit are extensive, is very important to study the phytochemical composition and biological activities promoted by other organs of this plant. Thus, the present study aimed investigates the phytochemical composition of the saline extract from Malpighia emarginata DC leaves and shows the initial biological activities promoted by this compound.

\section{MATERIALS AND METHODS}

\section{VEGETABLE MATERIAL AND EXTRACT} PREPARATION

The leaves of Malpighia emarginata were collected in the city of Recife, state of Pernambuco, Brazil. The botanical identification was performed by the Professor Marlene Barbosa, on May 30, 2017, at the Herbarium Geraldo Mariz, located at the Center of Biosciences of the Federal University of Pernambuco through exsiccate deposited under registration number 82.615. After collection, the leaves were kept at room temperature for drying during 4 days. The dried leaves were crushed in Reverse Black Oster and the pulverized material $(20 \mathrm{~g})$ was diluted in $0.15 \mathrm{M} \mathrm{NaCl}(200 \mathrm{~mL})$ in the proportion of $10 \%(\mathrm{w} / \mathrm{v})$. Therefore, using an orbital and alternative incubator shaker (Lab Companion ${ }^{\mathrm{TM}}$ IS-971) the material was kept under agitation (400 $\mathrm{rpm})$ in constant temperature $\left(28^{\circ} \mathrm{C}\right)$ for 16 hours. After the stirring time, the material was filtered using paper filter and centrifuged (15 min, 10,000 $x \mathrm{~g})$. The obtained supernatant was collected and called saline extract from Malpighia emarginata leaves. After this, the extract was lyophilized and 
$9.2 \mathrm{~g}$ of crude material was obtained. Material was stored at $-20{ }^{\circ} \mathrm{C}$ until use.

\section{DETERMINATION OF TOTAL PHENOLS}

The total phenols were determined by the FolinCiocalteu method according to Li et al. (2008) with some modifications. Extracts diluted at $1 \mathrm{mg} /$ $\mathrm{mL}$ were dissolved in distilled water. In $0.1 \mathrm{~mL}$ of Folin solution $(1: 10 \mathrm{v} / \mathrm{v})$ was added $0.02 \mathrm{~mL}$ of the diluted extracts. After 3 minutes of incubation (in the dark), 0.08 of sodium carbonate $(7.5 \%)$ was added and incubated for 120 minutes in the dark at room temperature. After this period, the absorbance of the samples was measured at $765 \mathrm{~nm}$ against a blank (reagent added to distilled water). A calibration curve was prepared by plotting the absorbance as a function of the concentration of gallic acid $(0-500 \mu \mathrm{g} / \mathrm{mL})$ was prepared and the linear equation $\left(y=0.0048 x+0.0016 R^{2}=0.9999\right)$. Phenols are expressed in gallic acid equivalent (mg EAG/g of extract).

\section{DETERMINATION OF FLAVONOID CONTENT}

The determination of flavonoids followed the methodology in accordance with Woisky and Salatino (1998) and Santos et al. (2017) with some modifications. The experiment consists of pipetting $1 \mathrm{~mL}$ of extract $(1 \mathrm{mg} / \mathrm{mL})$ in test tube. After this, $1 \mathrm{~mL}$ of aluminum chloride $\left(\mathrm{AlCl}_{3}, 5 \%\right)$ prepared in methanol $(2 \mathrm{~mL})$ was added in tubes. The blank was prepared using $3 \mathrm{~mL}$ of methanol and $1 \mathrm{~mL}$ of aluminum chloride. After 30 minutes of incubation (in dark) the absorbance was measured at $425 \mathrm{~nm}$. A standard curve with quercetin $(0-500 \mu \mathrm{g} / \mathrm{mL})$ was performed to obtain the equation $\mathrm{Y}=0.023 \mathrm{x}$ $+0.1509, \mathrm{R}^{2}=0.9956$. The assays were performed in quintuplicate. Flavonoids are expressed in quercetin equivalent (mg QE/g of extract).
ANALYSIS OF PHYTOCHEMICAL COMPOUNDS THROUGH OF ULTRA PERFORMANCE LIQUID CHROMATOGRAPHY COUPLED TO MASS SPECTROMETRY - UPLC-MS

Ultra-performance liquid chromatography (UPLC) was performed with an Acquity H-Class (Waters) employing a $2.1 \times 100 \mathrm{~mm}$ BEH column with a particle size of $1.7 \mu \mathrm{m}$. The column was maintained under a constant temperature of $40{ }^{\circ} \mathrm{C}$ and the auto injector at $10{ }^{\circ} \mathrm{C}$. We use an aqueous solution (eluent A) containing $2 \%$ methanol $(\mathrm{MeOH}), 5 \mathrm{Mm}$ ammonium formate and $0.1 \%$ formic acid and a methanol solution (eluent B) containing $0.1 \%$ formic acid, which were pumped at a flow rate of $0.3 \mathrm{~mL} / \mathrm{min}$. Ten microliters of the M. emarginata extract was injected. Elution was performed in gradient mode and the initial condition $(98 \% \mathrm{~A} /$ $2 \% \mathrm{~B}$ ) was maintained for 0.25 minutes. The $\mathrm{B}$ ratio increased linearly to $99 \%$ in 8.5 minutes, remaining at $99 \%$ B for one minute, followed by immediate decreased to $2 \% \mathrm{~B}$, where it was maintained for up to 11 minutes. The UPLC system was coupled to a single quadrupole mass spectrometer SQ Detector 2 (Waters ${ }^{\circledR}$ ). The data were obtained in fullscan mode, analyzing masses between 100 and 1000 $\mathrm{Da}$, in negative ionization. The acquisition of the chromatograms and mass spectra was obtained through MassLynx ${ }^{\text {TM }}$ software (Waters ${ }^{\circledR}$ ).

\section{EVALUATION OF ANTIOXIDANT ACTIVITIES IN} VITRO

\section{Total Antioxidant Activity}

The total antioxidant activity promoted by saline extract from Malpighia emarginata leaves was determined as a function of ascorbic acid, according with (Pietro et al. 1999). Saline extract $(100 \mu \mathrm{L}$ at $500 \mu \mathrm{g} / \mathrm{mL})$ was mixture with ascorbic acid $(1 \mathrm{mg} /$ $\mathrm{mL}$ ) and $1 \mathrm{~mL}$ of phosphomolybdenum solution (600 mM sulfuric acid, $28 \mathrm{mM}$ sodium phosphate and $4 \mathrm{mM}$ ammonium molybdate). This mixture was incubated in water at $95{ }^{\circ} \mathrm{C}$ for 90 minutes. 
After returning to room temperature, the absorbance are measured at $695 \mathrm{~nm}$ against a blank $(1 \mathrm{~mL}$ of solution and $0.1 \mathrm{~mL}$ of water). A standard curve with ascorbic acid $(0-500 \mu \mathrm{g} / \mathrm{mL})$ was performed to obtain the equation $\mathrm{Y}=0.019 \mathrm{x}+0.0723, \mathrm{R}^{2}=$ 0.9937 . Assays were performed in quintuplicate. Total antioxidant activity was calculated by the formula ATT $(\%)=[($ As - Ac) $/($ Aaa - Ac $)] 100$, where: Ac $=$ Control Absorbance, As $=$ Sample Absorbance and Aaa $=$ Ascorbic Acid Absorbance.

\section{Free radical sequestration by $D P P H$}

The antioxidant activity of saline extract was measured by the stable radical 2,2-diphenyl-1picrylhydrazyl (DPPH), as described by (Blois 1958). Using $0.04 \mathrm{~mL}$ of different concentrations of the saline extract $(3.9 ; 7.8 ; 15.6 ; 31.3 ; 62.5 ; 125 ; 250$ and $500 \mu \mathrm{g} / \mathrm{mL}$ ) it was added $0.25 \mathrm{~mL}$ of the DPPH solution $\left(1 \mathrm{mM}\right.$ and $\left.\mathrm{OD}_{517}=0.650 \pm 0.50\right)$. After incubation time ( 25 minutes) at room temperature, protected from light, the absorbance was measured at $517 \mathrm{~nm}$. We used as control the DPPH solution added to distilled water. Assays were performed in quintuplicate. The sequestration of DPPH radicals was calculated by the formula: SRL [DPPH $\left.{ }^{\circ}\right]$ $(\%)=[($ As - Ac $) / A c] \times 100$. When: As $=$ sample Absorbance and $\mathrm{Ac}=$ control Absorbance. The antioxidant activity of saline extract was measured by the stable radical 2,2-diphenyl-1-picrylhydrazyl (DPPH).

\section{Reduction of Ferric Ion (FRAP assay)}

The stock solution of the FRAP assay was prepared with $300 \mathrm{mM}$ acetate buffer $\left(3.1 \mathrm{~g} \mathrm{CH}_{3} \mathrm{COONa}\right.$ and $\left.16 \mathrm{~mL} \mathrm{CH}_{3} \mathrm{COOH}\right)$ at $\mathrm{pH} 3.6,10 \mathrm{mM}$ TPTZ (2.4, 6-tripyridyl-s-triazine) solubilized in $40 \mathrm{mM} \mathrm{HCl}$, and $20 \mathrm{mM} \mathrm{FeCl}_{3}$ solution. The working solution was prepared by mixing the acetate buffer, TPTZ and $\mathrm{FeCl}_{3}$ in a ratio of $10: 1: 1(\mathrm{v} / \mathrm{v} / \mathrm{v})$ and incubated for $5 \mathrm{~min}$ at $37{ }^{\circ} \mathrm{C}$. Saline extract $(25 \mu \mathrm{L}$ at $1 \mathrm{mg} /$ $\mathrm{mL}$ of concentration) was added in $180 \mu \mathrm{L}$ of
FRAP reagent and this solution was incubated for 30 minutes at $37^{\circ} \mathrm{C}$ in the dark. Subsequently the absorbance was measured at $593 \mathrm{~nm}$. A standard curve with $\mathrm{FeSO}_{4}(0-1000 \mu \mathrm{g} / \mathrm{mL})$ was performed to obtain the equation $\mathrm{Y}=0.0024 \mathrm{x}+0.0019, \mathrm{R}^{2}=$ 0.9953 . The results were expressed as mg EFeSO4 (II)/g of extract.

\section{ANTIMICROBIAL ASSAYS}

\section{Bacterial and fungal strains, culture conditions and preparation of samples}

Fungal strains were obtained from Micoteca of Mycology Department (URM) and the collection of microorganisms from the Department of Antibiotics (UFPEDA), both departments belonging to Biosciences Center of Federal University of Pernambuco. Stock cultures were kept under refrigeration $\left(-20{ }^{\circ} \mathrm{C}\right)$ in sterilized skimmed milk containing $10 \%(\mathrm{v} / \mathrm{v})$ glycerol or $30 \%$ (v/v) Mueller Hinton glycerol broth. Bacterial and fungal strains used in this study are: Candida albicans (URM 5901), Candida krusei (URM 6391), Candida tropicalis (URM 6551), Candida parapsilosis (URM 6951), Candida glabrata (URM 4246), Escherichia coli (UFPEDA 224), Klebsiella pneumoniae (UFPEDA 396), Pseudomonas aeruginosa (UFPEDA 416), Salmonella enteritidis (UFPEDA 414), Staphylococcus aureus (UFPEDA 02), Staphylococcus saprophyticcus (UFPEDA 833). For antimicrobial activity assays, bacterial and fungal species were cultured in Mueller Hinton and Sabouraud Dextrose agar medium, respectively, overnight at $36{ }^{\circ} \mathrm{C}$, and subsequently the colonies were resuspended in sterile saline solution $(0.15 \mathrm{M} \mathrm{NaCl})$ and adjusted turbidimetrically at a wavelength of $600 \mathrm{\eta m}\left(\mathrm{DO}_{600}\right)$ to obtain the suspension equivalent to $10^{6}$ colony forming units (CFU) per $\mathrm{mL}$. For the assay, the samples were filtered on the sterile polyvinylidene difluoride (PVDF) syringe filter of $13 \mathrm{~mm} \times 0.22 \mu \mathrm{m}$. 
Determination of Minimum Inhibitory

Concentration (MIC), Minimum Bactericidal

Concentration (MBC) and Minimum Fungicidal

Concentration (MFC)

The minimum inhibitory concentration (MIC) promoted by saline extract from Malpighia emarginata leaves was determined by the microtiter test proposed by the Clinical and Laboratory Standards Institute (CLSI). In 96well microtiter plates were added $(80 \mu \mathrm{L})$ into the fourth well from which a serial dilution in sterile Milli-Q water was performed to the twelfth well of the same row. Subsequently, $40 \mu \mathrm{L}$ of the medium Mueller Hinton broth (bacteria) or Sabouraud Dextrose (yeast) were added to all but the first wells, where $200 \mu \mathrm{L}$ of the culture medium was added, corresponding to the sterility control. The antibiotics ampicillin and tetracycline $(8 \mu \mathrm{g} / \mathrm{mL})$ and antifungal fluconazole $(64 \mu \mathrm{g} / \mathrm{mL})$ were used as positive controls in the second well. Finally, the bacterial and fungal suspension $(80 \mu \mathrm{L}, 106 \mathrm{CFU} /$ $\mathrm{mL}$ ) was added in the second well to the last well in the row. The third well (containing microorganisms in the absence of the sample) corresponded to the $100 \%$ growth control. The plates were incubated at $36{ }^{\circ} \mathrm{C}$ and the optical density was measured at time zero and after $24 \mathrm{~h}$ of incubation using a microplate reader. The Minimal Inhibitory Concentration MIC90 and MIC50 corresponded to the lowest concentration of the sample capable of promoting a reduction of $\geq 90 \%$ or $\geq 50 \%$, respectively, in optical density, as compared to the $100 \%$ growth control. For determination of Minimum Bactericidal Concentration (MBC) and Minimum Fungicidal Concentration (MFC), aliquots (10 $\mu \mathrm{L}$ ) of the wells containing concentrations of $\geq$ MIC50 samples were inoculated into petri dishes containing Mueller Hinton or Sabouraud Dextrose agar medium, which were subsequently incubated at $36^{\circ} \mathrm{C}$ for $24 \mathrm{~h}$. The MBC and MFC corresponded to the lower concentration of the sample able to reduce the number of $\mathrm{CFU}$ in $99.9 \%$ in relation to the initial inoculum. Each assay was performed in triplicate using three independent experiments.

\section{Antibiofilm Activity Analysis}

Biofilm formation was evaluated by the crystal violet method in flat bottom polystyrene microtiter plates. Then $80 \mu \mathrm{L}$ of Milli-Q water, $40 \mu \mathrm{L}$ of the Sabouraud Dextrose medium and $80 \mu \mathrm{L}$ of the fungal suspension $\left(10^{8} \mathrm{CFU} / \mathrm{mL}\right.$; sterile saline) were added, respectively. A $\mathrm{DO}_{600}$ was also launched using a microplate reader and as plates were incubated at $36{ }^{\circ} \mathrm{C}$ for $24 \mathrm{~h}$. After this period plates were read again to determinate the bacterial and/or fungal growth rate in $600 \mathrm{~nm}$. A sequential stage corresponds to the analysis of biofilm that is after sequencing of planktonic cells (unbound cells). In addition, the samples were washed with $0.15 \mathrm{M} \mathrm{NaCl}$ in pre-fixed methanol for $20 \mathrm{~min}$, followed by a setting at $50{ }^{\circ} \mathrm{C}$ for $60 \mathrm{~min}$ and then labeled with $0.4 \%(\mathrm{w} / \mathrm{v})$ crystal violet for $25 \mathrm{~min}$ at $25^{\circ} \mathrm{C}$. The wells were washed with water to remove unaccompanied violet crystal and subsequently the dye adhered to the biofilm was solubilized in absolute ethanol (20 min) and the absorbance was measured at $570 \eta \mathrm{m}$. All experiments were performed in triplicate.

\section{VIABILITY AND PROLIFERATION ASSAYS AGAINST MICE SPLENOCYTES}

\section{Animals}

Female BALB/c mice (6-8 weeks old; 5 animals) were raised and maintained at the animal facilities of the Keizo Asami Immunopathology Laboratory LIKA located in Federal University of Pernambuco, Brazil. Mice were kept under standard laboratory conditions $\left(20-22{ }^{\circ} \mathrm{C}\right.$ and $12 \mathrm{~h}$ day and night cycle) with free access to standard diet (Labina/Purina, Campinas, Brazil) and water. All experimental procedures were performed according to the Ethics Committee of Animal Use (CEUA) of Federal 
University of Pernambuco (protocol number: 0048/2016).

\section{Preparation of splenocytes}

This procedure was performed in accordance with Melo et al. 2011. After the inoculation of anesthetics $(10 \mathrm{mg} / \mathrm{Kg}$ of xylazine and $115 \mathrm{mg} / \mathrm{Kg}$ of ketamine i.p. injection) followed of cervical displacement, spleen of each mouse was removed aseptically and placed in a Falcon tube containing RPMI 1640 with fetal calf serum (complete medium). In a vertical flow, each spleen was transferred to a petri dish where they were soaked. The cell suspensions obtained from each spleen were transferred to Falcon tubes containing approximately $10 \mathrm{~mL}$ of incomplete medium. Spleen homogenates were overlaid onto Ficoll-Paque ${ }^{\mathrm{TM}}$ PLUS layer, with the density adjusted to $1.076 \mathrm{~g} / \mathrm{mL}$, and centrifuged at $1000 x \mathrm{~g}$ at room temperature for $25 \mathrm{~min}$. The interface cell layer containing immune cells was recovered by Pasteur pipette, washed twice in phosphate-buffered saline (PBS) and centrifuged twice at $500 x \mathrm{~g}$ for $10 \mathrm{~min}$. Cells were counted in a Neubauer chamber, and cell viability was determined by the trypan blue exclusion method. Cells were only used when viability was $>98 \%$.

\section{Analysis of cell viability by Annexin V-FITC and}

Propidium Iodide Staining

Mice splenocytes $\left(10^{6}\right.$ cells $)$ were treated with saline extract from Malpighia emarginata leaves at $50,25,12.5,6$ and $3 \mu \mathrm{g} / \mathrm{mL}$ and were maintained in 24-well plates for 24 hours to analyze their cell viability. Untreated cells (control) were used as a negative control. Following this, splenocytes were centrifuged at $4{ }^{\circ} \mathrm{C}, 450 x \mathrm{~g}$ for $10 \mathrm{~min}$. After discarding the supernatant, $1 \mathrm{~mL}$ of PBS $1 \mathrm{X}$ was added to the precipitate and centrifuged at $4{ }^{\circ} \mathrm{C}, 450$ $x \mathrm{~g}$ for $10 \mathrm{~min}$. After discarding the supernatant, the pellet was resuspended in a binding buffer of cell viability kit (Becton Dickinson Biosciences) and Annexin $\mathrm{V}$ conjugated with fluorescein isothiocyanate (FITC): $50 \mu \mathrm{g} / \mathrm{mL}$ ) and propidium iodide (PI, $20 \mu \mathrm{g} / \mathrm{mL}$ ) were added to each labeled cytometer tube. Flow cytometry was performed in a FACS Calibur (Becton Dickinson Biosciences) and analyzed using Cell Quest Pro software (Becton Dickinson). Result of the analysis was performed in graphs by dot plot. Annexin-FITC negative/PI positive cells were considered necrotic cells and Annexin-FITC positive/PI negative represented splenocytes in the early stage of apoptosis. Double negatives were considered viable cells.

\section{Cell proliferation analysis using CFSE staining}

Same protocol to obtained splenocytes was used for proliferation assay. After splenocytes obtainment, cell solution was centrifuged at $300 x$ $\mathrm{g}$ at room temperature for $5 \mathrm{~min}$ with sterile PBS $1 \mathrm{X}$ added with SFB 5\% (pH 7.2). After this, the cell solution was adjusted to $10 \times 10^{6}$ cells $/ \mathrm{mL}$ and received $5 \mathrm{mM}$ of 5(6)-carboxyfluorescein diacetate $\mathrm{N}$-succinimidyl ester (CFSE). Cells were incubated for $10 \mathrm{~min}$ at room temperature in the dark. Cells were centrifuged twice at $300 x \mathrm{~g} / 5 \mathrm{~min}$ with sterile PBS 1X. Cells stained were cultured for 24 and 48 hours with $12.5 \mu \mathrm{g} / \mathrm{mL}$ of saline extract from $M$. emarginata leaves and only culture complete RPMI 1640 medium (negative control). After culture time cells were centrifuged (300 $x \mathrm{~g} / 5 \mathrm{~min}$ ), were carry to acquisition on FACSCalibur platform (Becton Dickinson Biosciences) and results were analyzed using Cell Quest Pro software (Becton Dickinson).

\section{STATISTICAL ANALYSIS}

To test the normal hypothesis on the variable involved in this study the Shapiro-Wilke test was applied. Means of samples were analyzed using non-parametric tests. The statistical difference between two groups was analyzed by Wilcoxon test and that among more than three groups by one-way analysis of variance (ANOVA). All the conclusions 
were considered with a significance level of $5 \%$. For statistical analysis was used GraphPad Prim 5.01 software.

\section{RESULTS}

PREVALENCE OF PHENOLIC COMPOUNDS IN PHYTOCHEMICAL SCREENING OF SALINE EXTRACT FROM M. emarginata LEAVES

Results of analysis in UPLC-MS about the phytochemical characterization of saline extract from M. emarginata leaves (Figure 1) showed that was found many phenolic compounds being some compounds belonged flavonoid (Table I).
In addition, we found 18 compounds in the saline extract in accordance with the area, retention time, molecular weight, molecular formula and negative mass, identifying other phenolic compounds, like Protocatechuic acid, Apigenin7-O- glucoside flavonoid and terpenoids, like Isotriptophenolide (see Table II).

\section{SALINE EXTRACT FROM $M$. emarginata LEAVES} SHOWED SIGNIFICANT ANTIOXIDANT POWER

Saline extract from M. emarginata leaves showed higher antioxidant power being five times superior to butylated hydroxytoluene (BHT) standard $(20.32 \pm 0.89 / 4.12 \pm 0.10$ to saline extract and BHT, respectively). Saline extract also was able to

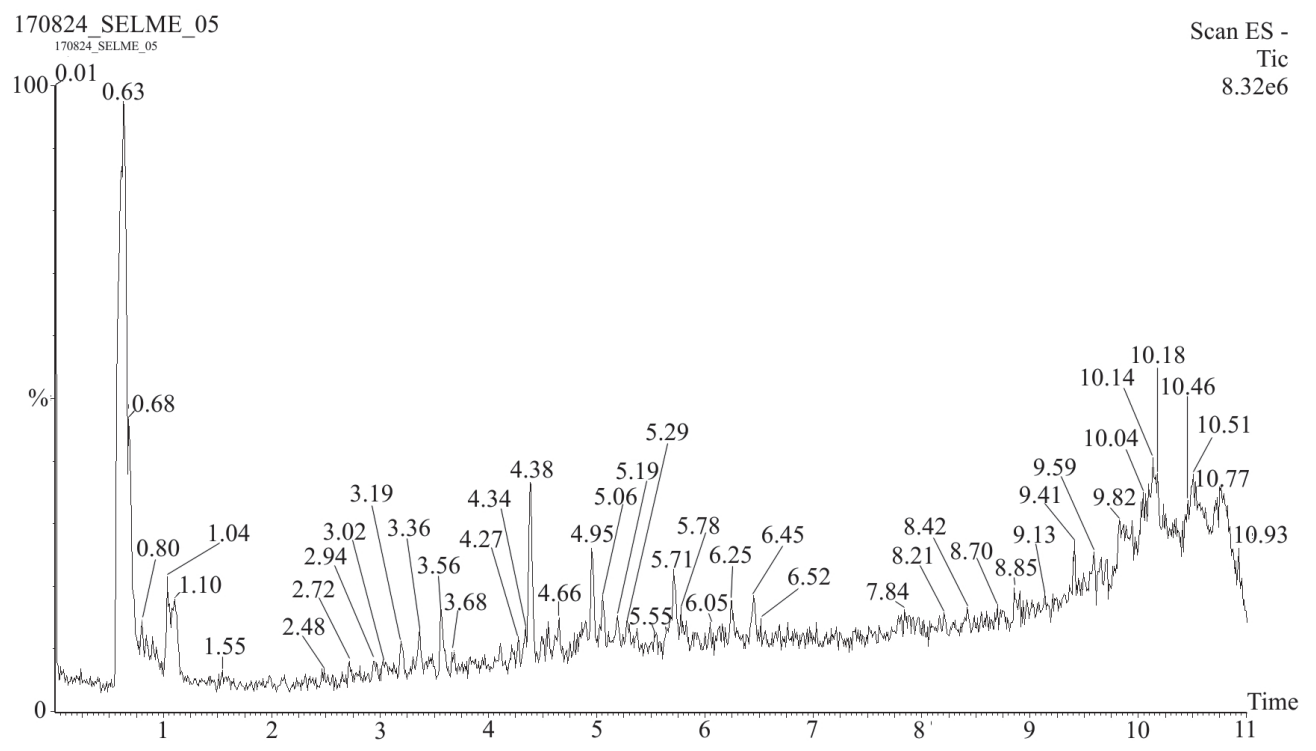

Figure 1 - UPLC-MS Chromatogram of saline extract from M. emarginata leaves.

TABLE I

Result of antioxidant activities and phenol amounts found on saline extract from M. emarginata leaves.

\begin{tabular}{lccc}
\hline & M. emarginata & BHT & Ascorbic acid \\
\cline { 2 - 3 } Total phenolic compounds (mg GAE/g) & $51.14 \pm 0.21$ & - & - \\
Total of flavonoids (mg QE/g) & $9.67 \pm 0.08$ & - & - \\
Free radical sequestration by DPPH $(\% \mathrm{mg} / \mathrm{mL})$ & $38.59 \pm 1.20$ & $93.13 \pm 0.58$ & $90.04 \pm 0.16$ \\
Total antioxidant capacity (mg AAE/g) & $20.32 \pm 0.89$ & $4.12 \pm 0.10$ & 100 \\
Reduction of Ferric Ion (EFeSO4(II)/g) & $416.11 \pm 0.46$ & $679.17 \pm 25.98$ & $1215 \pm 48.55$ \\
\hline
\end{tabular}


TABLE II

UPLC-MS spectral analysis of compounds found in saline extract from M. emarginata leaves.

\begin{tabular}{|c|c|c|c|c|c|}
\hline COMPOUNDS & $\begin{array}{l}\text { RETENTION } \\
\text { TIME (min) }\end{array}$ & $\begin{array}{l}\text { MOLECULAR } \\
\text { FORMULA }\end{array}$ & AREA & MASS & [M-H]- \\
\hline Rhinocerotinoic acid & 0.63 & $\mathrm{C}_{20} \mathrm{H}_{30} \mathrm{O}_{3}$ & 5.756 .062 & 318.457 & 317.211 \\
\hline Quinic Acid & 1.06 & $\mathrm{C}_{7} \mathrm{H}_{12} \mathrm{O}_{6}$ & 105.468 .063 & 192.063 & 192.063 \\
\hline Dimethoxycurcumin & 2.72 & $\mathrm{C}_{23} \mathrm{H}_{24} \mathrm{O}_{6}$ & 5.840 .279 & 396.439 & 395.149 \\
\hline Protocatechuic Acid & 3.36 & $\mathrm{C}_{7} \mathrm{H}_{6} \mathrm{O}_{4}$ & 16.625 .830 & 154.026 & 153.018 \\
\hline Tolypodiol & 3.60 & $\mathrm{C}_{28} \mathrm{H}_{40} \mathrm{O}_{5}$ & 6.356 .449 & 456.623 & 455.279 \\
\hline Pauciflorol A & 3.90 & $\mathrm{C}_{20} \mathrm{H}_{34} \mathrm{O}_{2}$ & 73.426 .766 & 306.255 & 305.248 \\
\hline Gentisic acid & 4.25 & $\mathrm{C}_{7} \mathrm{H}_{6} \mathrm{O}_{4}$ & 5.425 .569 & 154.026 & 153.018 \\
\hline Matricin & 4.38 & $\mathrm{C}_{17} \mathrm{H}_{22} \mathrm{O}_{5}$ & 73.426 .766 & 306.358 & 305.138 \\
\hline Gallocatechin & 4.38 & $\mathrm{C}_{15} \mathrm{H}_{14} \mathrm{O}_{7}$ & 7.342 .677 & 306.27 & 305.066 \\
\hline $\begin{array}{l}\text { 11a-hidroxi-3,7-dioxo-5a-lanosta-8,24 } \\
\text { (E)-dien-26-oic Acid }\end{array}$ & 4.49 & $\mathrm{C}_{30} \mathrm{H}_{44} \mathrm{O}_{5}$ & 7.038 .835 & 484,318 & 483,311 \\
\hline Protocatechuic acid & 4.65 & $\mathrm{C}_{7} \mathrm{H}_{6} \mathrm{O}_{4}$ & 5.425 .569 & 154.121 & 153.018 \\
\hline Cicutoxin & 5.19 & $\mathrm{C}_{17} \mathrm{H}_{22} \mathrm{O}_{2}$ & 6.584 .033 & 258.355 & 225.164 \\
\hline Salicylic acid & 5.71 & $\mathrm{C}_{7} \mathrm{H}_{6} \mathrm{O}_{3}$ & 31.334 .580 & 138.031 & 137.023 \\
\hline 2,5 Dihydroxybenzaldehyde & 5.71 & $\mathrm{C}_{7} \mathrm{H}_{6} \mathrm{O}_{3}$ & 31.334 .580 & 138.031 & 137.023 \\
\hline Apigenin-7-O- glucoside & 8.86 & $\mathrm{C}_{21} \mathrm{H}_{20} \mathrm{O}_{10}$ & 6.690 .703 & 432.105 & 431.097 \\
\hline Magnosalicin & 8.87 & $\mathrm{C}_{24} \mathrm{H}_{32} \mathrm{O}_{7}$ & 6.690 .703 & 432.513 & 431.207 \\
\hline Apigenin-8-O- glucoside & 8.87 & $\mathrm{C}_{21} \mathrm{H}_{20} \mathrm{O}_{10}$ & 6.690 .703 & 432.381 & 431.097 \\
\hline Isotriptophenolide & 9.85 & $\mathrm{C}_{20} \mathrm{H}_{24} \mathrm{O}_{3}$ & 50.121 .777 & 312.409 & 311.164 \\
\hline
\end{tabular}

increase of free radical sequestration $(38,59 \%)$ and promoted higher ferric ion reduction, also like BHT standard (see Table I).

\section{HIGHER ANTIFUNGAL ACTIVITY WAS PROMOTED BY SALINE EXTRACT}

Six bacterial species tested showed resistance to the extract. However, the saline extract from $M$. emarginata leaves inhibited $90 \%$ of growth capacity of Candida albicans, Candida parapsilosis, Candida krusei and Candida tropicalis in lower concentrations (Table III). In addition, was also possible observe that saline extract presented more significant results as antifungal against $C$. albicans and C. parapsilosis, comparing to the other species. Only the $C$. glabrata species was resistant to saline extract.

Antibiofilm activity was evaluated with the saline extract following the concentrations of MICs: 64 MIC, 16 MIC, 4 MIC, MIC, 1/4 MIC, $1 / 16 \mathrm{MIC}$ and 1/64 MIC; according to the graphs in figure 2 and Table IV. 
TABLE III

Antifungal activity against Candida spp. Promoted by saline extract from Malpighia emarginata leaves.

\begin{tabular}{|c|c|c|c|c|}
\hline \multirow[t]{2}{*}{ Strains } & \multirow{2}{*}{$\begin{array}{c}\begin{array}{c}\text { Fluconazole } \\
(\mu \mathrm{g} / \mathrm{mL})\end{array} \\
\text { MIC }_{\mathbf{5 0}}\end{array}$} & \multicolumn{3}{|c|}{$\begin{array}{l}\text { Saline extract from } M \text {. emarginata leaves } \\
\qquad(\mu \mathrm{g} / \mathrm{mL})\end{array}$} \\
\hline & & $\mathrm{MIC}_{50}$ & $\mathrm{MIC}_{90}$ & MFC \\
\hline C. albicans & 0.25 & 0.51 & 0.52 & ND \\
\hline C. parapsilosis & ND & 0.51 & 0.51 & 0.51 \\
\hline C. krusei & 32 & 8.36 & 8.36 & ND \\
\hline C. tropicalis & 4 & 0.13 & 0.26 & 1.05 \\
\hline C. glabrata & 64 & ND & ND & ND \\
\hline
\end{tabular}
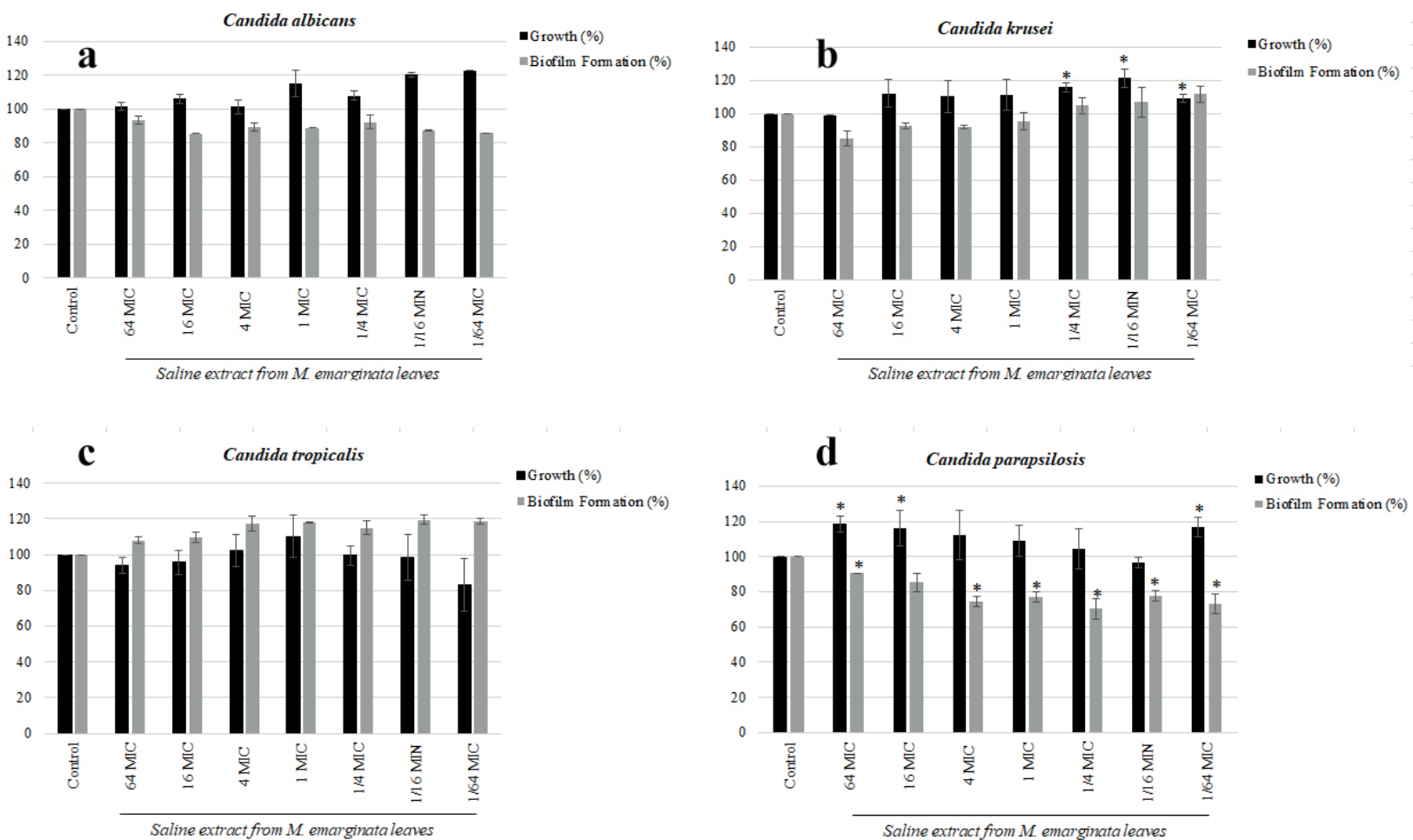

Figure 2 - Analysis of the antibiofilm activity of Malpighia emarginata saline extract to species of Candida albicans (a), Candida krusei (b), Candida tropicalis (c) and Candida parapsilosis (d). Assays performed in triplicate. $\mathrm{p}<0.002$. 
TABLE IV

Results on the antibiofilm activity of Malpighia emarginata saline extract, in percentage, of Candida ssp. tested.

\begin{tabular}{|c|c|c|c|c|c|c|c|c|}
\hline \multicolumn{9}{|c|}{ Value\% of growth $\left(\mathrm{DO}_{600}\right)$ of Candida ssp. (mean) $\mathrm{DO}_{600}$} \\
\hline & Control & $64 \mathrm{MIC}$ & $16 \mathrm{MIC}$ & 4 MIC & $1 \mathrm{MIC}$ & 1/4 MIC & 1/16 MIC & 1/64 MIC \\
\hline C. albicans & 100 & 104.3 & 105.5 & 105.1 & 109.1 & 105.3 & 120.5 & 122.6 \\
\hline C. krusei & 100 & 99 & 112.4 & 110.4 & 111.3 & 116.1 & 121.4 & 109.3 \\
\hline C. tropicalis & 100 & 94 & 95.6 & 102.5 & 110.2 & 99.7 & 98.4 & 83.1 \\
\hline C. parapsilosis & 100 & 118.7 & 116.4 & 112.2 & 109 & 104.3 & 96.6 & 116.8 \\
\hline \multicolumn{9}{|c|}{ Value\% of biofilm biomass of Candida spp. (mean) } \\
\hline & Control & $64 \mathrm{MIC}$ & $16 \mathrm{MIC}$ & 4 MIC & $1 \mathrm{MIC}$ & 1/4 MIC & 1/16 MIC & 1/64 MIC \\
\hline C. albicans & 100 & 93.4 & 85.5 & 87.7 & 88.7 & 89.2 & 87.2 & 85.8 \\
\hline C. krusei & 100 & 85 & 92.7 & 92 & 95.4 & 104.9 & 107 & 111.9 \\
\hline C. tropicalis & 100 & 107.9 & 109.7 & 117.3 & 118 & 115 & 119,6 & 118.6 \\
\hline C. parapsilosis & 100 & 90.5 & 85.3 & 74.3 & 77.2 & 70.4 & 77.5 & 73.3 \\
\hline
\end{tabular}

The results of the antibiofilm activity confirm the antimicrobial tests performed. The saline extract of Malpighia emarginata presented a considerable reduction in the biofilm formation of $C$. albicans, C. krusei and C. parapsilosis species, as described in table IV.

\section{SALINE EXTRACT FROM $M$. emarginata LEAVES NOT INDUCED CELL DAMAGE AND PROMOTED HIGHER CELL PROLIFERATION IN MICE SPLEEN CELLS}

Mice Balb/c spleen cells treated with saline extract in different concentrations (50, 25, 2.5, 6 and $3 \mu \mathrm{g} /$ $\mathrm{mL}$ ), did not suffer significant cell death, for both apoptosis and necrosis, in none concentrations evaluated (Figure 3). In fact, saline extract from M. emarginata leaves promoted a higher cellular viability, superior to $90 \%$ of surviving. For measuring if saline extract was able to activate immune spleen cells, we performed other assay to investigate the proliferation index of these cells challenged with only one concentration of extract $(12.5 \mu \mathrm{g} / \mathrm{mL})$ during two days of cell culture. Results showed that saline extract from M. emarginata leaves induced higher proliferation indices in both times evaluated (Figure 4).

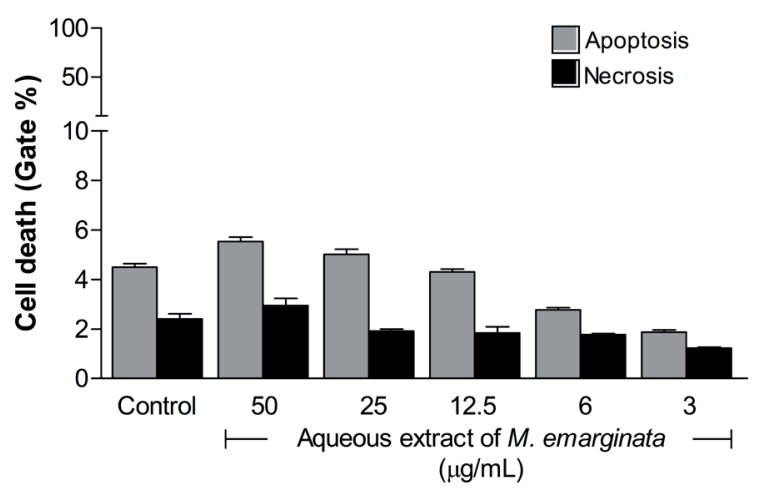

Figure 3 - Mice splenocytes viability evaluated using annexin $\mathrm{V}$ and propidium iodide staining. Saline extract from $M$. emarginata leaves did not promoted cell death in none concentration. Horizontal bars represent the average of three independent experiments performed in duplicate. Results were evaluated in the significance level of $5 \%$.

\section{DISCUSSION}

Popular culture collaborates with the indiscriminate use of medicinal plants within the context of selfmedication, requiring the study of its constituents, the mechanism of therapeutic action and the identification of active principles responsible for the various biological activities reported by the population (Ford et al. 2014). Here, we used a saline extract made from $M$. emarginata leaves. The proposal was investigated if an extract of plant, 


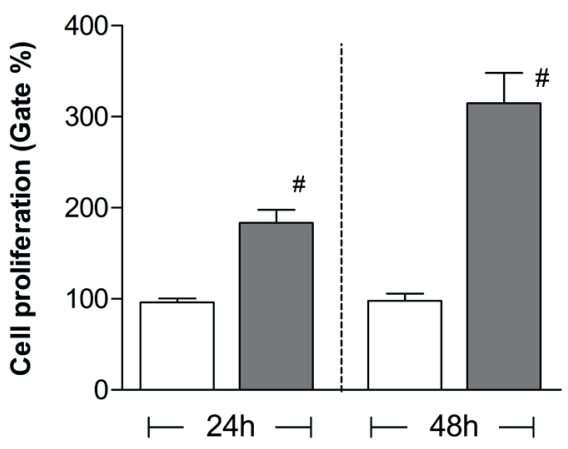

Figure 4 - Mice splenocytes proliferation index evaluated using CFSE staining. Saline extract from $M$. emarginata leaves promoted proliferation in mice splenocytes in both times evaluated ( 24 and 48 hours of assay). Vertical white bars represent negative control cells (cells + culture medium) and vertical gray bars represent saline extract from $M$. emarginata leaves at $12.5 \mu \mathrm{g} / \mathrm{mL}$ concentration. This assay was performed using three independent experiments performed in duplicate. $\# \mathrm{P}=0.003$.

made with standard physiological solution $(\mathrm{NaCl}$ $0.15 \mathrm{M}$ ), is cytotoxic to cells and microorganisms and if this extract is also able to be antioxidant.

In similarity to the results found by Wong et al. (2008) and Nowotarska et al. (2017), the saline extract from leaves of M. emarginata, as described in Table II prepared in its phytochemicals 18 characterized compounds, being a larger number of a class of phenolic and terpenoid compounds.

Among the compounds described are the apigenin-7-O-glucoside and Apigenin-8-Cglucoside flavonoids extensively studied and described in the literature for their potential applicability as anti-inflammatory agents (Kowalski et al. 2005) and antitumor agents (Bankeu et al. 2017, Smiljkovic et al. 2017, Zhao et al. 2017). In addition, Apigenin-8-C-glucoside is a biologically active molecule with potential antihypertensive, antidepressant, antispasmodic and antioxidant effect (Ele et al. 2016).

As described in Table I, saline extract from $M$. emarginata leaves showed a potential antioxidant capacity, especially when compared to butylated hydroxytoluene (BHT) a known antioxidant compound used as standard (Pasa et al. 2016, Nascimento et al. 2017). We suggest that this antioxidant potential is due to higher amounts of phenolic compounds, previously described in several studies as antioxidants molecules (Zengin et al. 2018). Similar to our results, other studies also showed that plants rich in phenolic compounds have antioxidant potential as well as the extracts of Ficus beecheyana (Yen et al. 2018), Punica granatum (Russo et al. 2018) and Saccharum officinarum (Abbas et al. 2014). Moreover, Nascimento et al. (2017) analyzed the antioxidant activity of Malpighia glabra fruits at various stages of maturation, thus finding high levels of antioxidant activity and, consequently, the presence of phenolic compounds.

Organic extracts from various organs of $M$. emarginata presented potential antimicrobial activity against different pathogenic bacteria species as described by Silva (2014) and Motohashi et al. (2004). Although such solvents (hexane and ethyl acetate) have high toxicity to microorganisms (Yung et al. 2016), the indiscriminate use of these solvents is also associated with intoxication, either by ingestion or inhalation, causing serious damage to the individual, such as severe lung injury and hepatotoxicity (Ford et al. 2014, Tormohelen et al. 2014, Connellan, 2017).

The results obtained in this study did not show action against the species of bacteria used. However, the saline extract of $M$. emarginata leaves presented a potential fungicidal, fungistatic and antibiofilm action, suggesting this capacity, once again, to the presence of phenolic compounds (Haghdoost et al. 2016, Barral et al. 2017, Jara et al. Wang et al. 2018).

As described by Khan et al. (2014) and Glorybai et al. (2015) plants are commonly used by traditional medicine as a source of cure for various diseases. However, the irrational use or the conception that a natural product does not cause harm to the health can be harmful to the individual, 
being associated to diverse problems like poisoning and anaphylactic shocks (Lin et al. 2018), being the toxicological studies of medicinal plants, of great relevance to the security of the individual (Saleh-eIn \& Staden, 2018).

Here we also investigate the cytotoxicity profile promoted by the saline extract from $M$. emarginata leaves in mice splenocytes and the results showed that, same in higher concentrations, this extract is not toxic. Moreover, M. emarginata extract also promoted lymphocyte proliferation in both 24 and 48 hours of incubation, suggesting immunostimulatory properties. Recent study showed that extract of several species of Byrsonima spp. (Malpighiaceae) in different concentrations $(12.5$ and $50 \mu \mathrm{g} / \mathrm{mL})$ were not cytotoxic against RAW 264-7 cells (Fraige et al. 2018). In 2016, Düsman et al. evaluated the cytotoxicity of the aqueous extract from Malpighia glabra Linnaeus fruits in vivo and in vitro in Wistar rats, and against bone marrow derived cells from these animals. Their results demonstrated that the extract also was not cytotoxic.

The activation and cellular proliferation are directly associated with healing processes and with the replacement of dead cells of the tissues that are in constant development in the organism. For this, is very important investigate if a compound can promote cell proliferation, especially if these cells are immunological because the major activation mechanism of lymphocytes is the clonal expansion after it activation.

Plants extracts belonging to the Malpighiaceae family also present other potential pharmacological properties, such as antimicrobial, wound healing and antitumor (Düsman et al. 2016, Specian et al. 2016).

Recent studies with different species belonging to the genus Byrsonima (family Malpighiaceae) showed no cytotoxic action against different human cell lines (monocytes and cells of primary gastric epithelium) but demonstrated a potential cytotoxic capacity against colon cancer cell lines (HT29) and hepatocellular carcinoma (HepG2) (Specian et al. 2016, Verdam et al. 2014). Our results associated with these findings suggest the possibility of future investigations about antitumor, wound healing and immunological responses promoted by saline extract from Malpighia emarginata leaves.

\section{CONCLUSIONS}

Saline extract from Malpighia emarginata leaves showed the presence of a considerable concentration of total phenolic compounds, among them some flavonoids and phenolic acids. Moreover, showed antioxidant and antifungal properties and was not cytotoxicity against mice splenocytes, inducing high proliferation in these cells. These results are promisors, demonstrate the safe use of this plant against normal cells and stimulate new investigations to use this extract like antifungal and immunostimulant compound in future assays.

\section{ACKNOWLEDGMENTS}

The authors express their thanks to teacher Marlene Barbosa, curator of Herbarium Geraldo Mariz, to the Center for Strategic Technologies of the Northeast (CETENE), to the Laboratory of Protein Biochemistry; Biophysics; Biotechnological Processes; Immunological and Antitumor Analyzes and the Nucleus of Technological Platforms of the Research Center Aggeu Magalhães (FIOCRUZ Pernambuco). The authors declare no conflict of interest.

\section{AUTHOR CONTRIBUTIONS}

B. Barros and B. Barboza performed the antioxidant, antimicrobial and immunological assays, as well as writing of the manuscript; B. Ramos and M. Moura performed the antimicrobial assays; L. Coelho, T. Napoleão, M. Correia, P. Paiva and C. Lima made available different reagents and equipment 
to investigate both leaves and saline extract; I. Cruz Filho and T. Silva performed the structural and phytochemical analysis; C. Melo helped in experimental design, immunological assays and writing of the manuscript.

\section{REFERENCES}

ABBAS SR, SABIR SM, AHMAD SD, BOLIGON AA AND ATHAYDE ML. 2014. Phenolic profile, antioxidant potential and DNA damage protecting activity of sugarcane (Saccharum officinarum). Food Chem 147: 10-16.

ALVAREZ-SUAREZ JM ET AL. 2017. The protective effect of acerola (Malpighia emarginata) against oxidative damage in human dermal fibroblasts through the improvement of antioxidant enzyme activity and mitochondrial functionality. Food Funct 8(9): 3250-3258.

ASGARI S, SETORKI M, RAFIEIAN-KOPAEI M, HEIDERMICO E, SHAHINFARD N, ANSARI E AND FOROUZANDEH Z. 2012. Postprandial hypolipidemic and hypoglycemic effects of Allium hertifolium and Sesamum indicum on hypercholesterolemic rabbits. Afr J Pharm Pharmacol 6: 1131-1135.

ASGARY S, MOSHTAGHIAN SJ, SETORKI M, KAZEMI S, RAFIEIAN-KOPAEI M, ADELNIA A AND SHAMSI F. 2011. Hypoglycaemic and hypolipidemic effects of pumpkin (Cucurbita pepo L.) on alloxan-induced diabetic rats. Afr J Pharm Pharmacol 5: 2620-2626.

BANKEU KJJ, DIETAGOUM MS, KUMAR R, ALI MS, LENTA NB AND YOUSUF S. 2017. Crystal structure and Hirshfeld surface analysis of 3-oxours-12-ene-27a,28dioic acid (quafrinoic acid). Acta Crystallogr E 73(5): 763766.

BARRAL B, CHILLET M, MINIER J, LECHAUDEL M AND SCHORR-GALINDO S. 2017. Evaluating the response to Fusarium ananatum inoculation and antifungal activity of phenolic acids in pineapple. Fungal Biol 121: 1045-1053.

BATAGLION GA, SILVA FMA, EBERLIN MN AND KOOLEN HHF. 2015. Determination of the phenolic composition from Brazilian tropical fruits by UHPLCMS/MS. Food Chem 180: 280-287.

BLOIS MS. 1958. Antioxidant Determinations by the Use of a Stable Free Radical. Nature 181: 1199-1200.

CONNELLAN SJ. 2017. Lung diseases associated with hydrocarbon exposure. Resp Med 126: 46-51.

DÜSMAN E, ALMEIDA IV, TONIN LTD AND VICENTINI VEP. 2016. In vivo antimutagenic effects of the Barbados cherry fruit (Malpighia glabra Linnaeus) in a chromosomal aberration assay. Genet Mol Res 15(4).

ELE M, MIN JW, KONG WL, ELE XH, LI JX AND PENG BW. 2016. A review of the pharmacological effects of Vitexin and isovitexin. Phytotherapy 115: 74-85.
FRAIGE K ET AL. 2018. Dereplication by HPLC-DADESI-MS/MS and Screening for Biological Activities of Byrsonima Species (Malpighiaceae). Phytochem Anal 29: 196-204.

FORD JB, SUTTER ME, OWEN K AND ALBERTSON TE. 2014. Volatile Substance Misure: An Updated Review of Toxicity and Treatment. Clin Rev Allergy Immunol 46: 19-33.

GLORYBAI L, KANNAN KB, ARASU MV, AL-DHABI NA AND AGASTIAN P. 2015. Some biological activities of Epaltes divaricata L. - an in vitro study. Annals of Clinical Microbiology and Antimicrobials. 14: 18.

HAGHDOOST NS, SALEHI TZ, KHOSRAVI A AND SHARIFZADEH A. 2016. Antifungal activity and influence of propolis against germ tube formation as a critical virulence attribute by clinical isolates of Candida albicans. J Mycol Med 26(4): 298-305.

JARA C, LEYTON M, OSORIO M, SILVA V, FLEMING F AND PAZ M. 2017. Antioxidant, phenolic and antifungal profiles of Acanthus mollis (Acanthaceae). Nat Prod Res 31(19).

KHAN N, ABBASI AM, DASTAGIR G, NAZIR A, SHAH GM, SHAH MM AND SHAH MH. 2014. Ethnobotanical and antimicrobial study of some selected medicinal plants used in Khyber Pakhtunkhwa (KPK) as a potential source to cure infectious diseases. BMC Complement Altern Med 14: 122.

KOWALSKI J, SAMOJEDNY A, PAUL M, PIETSZ G AND WILCZOK T. 2005. Effect of apigenin, kaempferol and resveratrol on the expression of interleukin-1beta and tumor necrosis factor-alpha genes in J774.2 macrophages. Rep Pharmacol 57(3): 390-394.

LEFFA DD ET AL. 2014. Corrective effects of acerola (Malpighia emarginata DC.) juice intake on biochemical and genotoxical parameters in mice fed on a high-fat diet. Mutat Res 770: 144-52.

LI HB, WONG CC CHENG KW AND CHEN F. 2008. Antioxidant properties in vitro and total phenolic contents in methanol extracts from medicinal plants. LWT Food Sci Technol 41(3): 385-390.

LIN L, LIU YC, HUANG JL, LIU XB, QING ZX, ZENG JG AND LIU ZY. 2018. Medicinal plants of the genus Macleaya (Macleaya cordata, Macleaya microcarpa): A review of their phytochemistry, pharmacology, and toxicology. Phytother Res 32(1): 19-48.

MALEGORI C, NASCIMENTO MEJ, DE FREITAS ST, PIMENTEL MF, PASQUINI C AND CASIRAGHI E. 2017. Comparing the analytical performances of MicroNIR and FT-NIR spectrometers in the evaluation of acerola fruit quality, using PLS and SVM regression algorithms. Talanta 165: 112-11.

MELO CML, PORTO CS, MELO-JÚNIOR MR, MENDES CM, CAVALCANTI CCB, COELHO LCBB, PORTO 
ALF, LEÃO AMAC AND CORREIA MTS. 2011. Healing activity induced by Cramoll 1,4 lectin in healthy and immunocompromised mice. Int J Pharmaceutics 408: 113119.

MEZADRI, T, VILLANO D, FERNANDEZ-PACHON MS, GARCIA-PARRILLA MC AND TRONCOSO AM. 2008. Antioxidant compounds and antioxidant activity in acerola (Malpighia emarginata DC.) fruits and derivatives. J Food Compos Anal 21: 282-290.

MEZQUITA PC AND VIGOA YG. 2000. La acerola. Fruta marginada de América con alto contenido en Ácido ascorbico. Alimentaria 1: 113-125.

MOREIRA AA, MARTINS LSS, MUSSER RS, MORAES FILHO RM, MARANHÃO WA, ROSSITER JG AND MONTARROYOS AVV. 2016. Response of Malpighia emarginata active germplasm bank accessions to Meloidogyne enterolobii parasitism. Genet Mol Res 15(4).

MOTOHASHI N ET AL. 2004. Biological activity of barbados cherry (acerola fruits, fruit of Malpighia emarginata DC) extracts and fractions. Phytother Res 18: 212-223.

NASCIMENTO EMM, RODRIGUES FG, COSTA WD, TEIXEIRA RNP, BOLIGON AA, SOUZA EO, RODRIGUES FFG, COUTINHO HDM AND COSTA JGM. 2017. HPLC and in vitro evaluation of antioxidant properties of fruit from Malpighia glabra (Malpighiaceae) at different stages of maturation. Food Chem Toxicol 26.

NOWOTARSKA SW, NOWOTARSKI K, GRANT IR, ELLIOTT CT, FRIEDMAN M AND SITU C. 2017. Mechanisms of Antimicrobial Action of Cinnamon and Oregano Oils, Cinnamaldehyde, Carvacrol, 2,5-Dihydroxybenzaldehyde, and 2-Hydroxy-5Methoxybenzaldehyde against Mycobacterium avium subsp. paratuberculosis (Map). Foods 6(9): 72.

OLIVEIRA LS, MOURA CFH, BRITO ES, MAMEDE RVS AND MIRANDA MRA. 2012. Antioxidant Metabolism during Fruit Development of Different Acerola (Malpighia emarginata D.C) Clones. J Agric Food Chem 60(32): 7957-7964.

PASA S, AYDIN S, KALAYCI S, BOGA M, ATLA M, BINGUL M, SAHIN F AND TEMEL H. 2016. The synthesis of boronic-imine structured compounds and identification of their anticancer, antimicrobial and antioxidant activities. J Pharm Anal 6: 39-48.

PIETRO P, PINEDA M AND AGUILAR M. 1999. Spectrophotometric quantification of antioxidante capacity through the formation of a phosphomolybdenum complex: specific application to the determination of vitamin $\mathrm{E}$. Anal Biochem 269(2): 337-341.

ROSSO VV, HILLEBRANDB S, MONTILLAB EC, BOBBIO FO, WINTERHALTER P AND MERCADANTE AZ. 2008. Determination of anthocyanins from acerola (Malpighia emarginata DC.) and açaí (Euterpe oleracea
Mart.) by HPLC-PDA-MS/MS. J Food Compos Anal 21: 291-299.

RUSSO M, FANALI C, TRIPODO G, DUGO P, MULEO R, DUGO L, DE GARA L AND MONDELLO L. 2018. Analysis of phenolic compounds in different parts of pomegranate (Punica granatum) fruit by HPLC-PDA-ESI/ MS and evaluation of their antioxidant activity: application to different Italian varieties. Anal Bioanalytic Chem 1-14.

SALEH-E-IN M AND STADEN JV. 2018. Ethnobotany, phytochemistry and pharmacology of Arctotis arctotoides (L.f.) O. Hoffm.: A review. J Ethnopharmacol 11.

SANTOS L, HOCHHEIM S, BOEDER MA, KROGER A, TOMAZZOLI MM, NETO RDP, MARASCHIN M, GUEDES A AND CÓRDOBA CMM. 2017. Chemical characterization, antioxidant, cytotoxic and antibacterial activity of extracts of propolis and compounds isolated from Brazilian unleavened bees Melipona quadrifasciata eTetragonisca angustula. J Apicult Res 56(5): 543-558.

SEERAM NP AND NAIR M. 2002. Inhibition of lipid peroxidation and structure-activity related studies of the dietary constituents anthocyanins, anthocyanidins, and catechins. J Agric Food Chem 50: 5308-5312.

SHIRZAD H, TAJI F AND RAFIEIAN-KOPAEI M. 2011. Correlation between antioxidant activity of garlic extracts and WEHI-164 fibrosarcoma tumor growth in BALB/c mice. J Med Food 14: 969-974.

SMILJKOVIC M ET AL. 2017. Apigenin-7-O-glucoside versus apigenin: Insight into the modes of anticandidal and cytotoxic actions. EXCLI J 16: 795-807.

SPECIAN AFL, SERPELONI JM, TULLIS K, RIBEIRO DL, COLIÃO HL, VARANDA EA, SANNOMIYA M, MARTINEZ-LOPES W, VILEGAS W AND CÓLUS IMS. 2016. LDH, proliferation curves and cell cycle analysis are the most suitable assays to identify and characterize new phytotherapeutic compounds. Cytotechnol 68: 2729-2744.

TORMOHELEN LM, TEKULVE KJ AND NAÑAGAS KA. 2014. Hydrocarbon toxicity: A review. J Clin Toxicol 52: 479-489.

VERDAM MCS, GUILHON-SIMPLICIO F, PAULA CS, OLIVEIRA VB, MIGUEL MD, CAMPELO PMS AND MIGUEL OG. 2014. Cytotoxicity of Byrsonima duckeana W.R. Anderson (Malpighiaceae) on colon cancer cells. Int J Pharm Pharmac Sci 6(11).

WANG H, CAO GH AND PRIOR RL. 1997. Oxygen radical absorbing capacity of anthocyanins. J Agric Food Chem 45: 304-309.

WANG W, JIANG S, PU T, FAN L, SU F AND YE M. 2018. Antifungal activity of phenolic monoterpenes and structure-related compounds against plant pathogenic fungi. Nat Prod Res 0: 1-8.

WOISKY RG AND SALATINO A. 1998. Analysis os propolis: some parameters and prodecore for chemical fuality control. J Apic Res. 
WONG SYY, GRANT IR, FRIEDMAN M AND ELLIOTT CT, SITU C. 2008. Antibacterial Activities of Naturally Occurring Compounds against Mycobacterium avium subsp. paratuberculosis. Appl Environ Microbiol 74(19): 5986-5990.

YEN GC, CHEN CS, CHANG WT, WU MF, CHENG FT, SHIAU DK AND HSU CL. 2018. Antioxidant activity and anticancer effect of ethanolic and aqueous extracts of the roots of Ficus beecheyana and their phenolic components. J Food Drug Anal. 26: 182-192.

YUNG PY, GRASSO LL, MOHIDIN AF, ACERBI E, HINKS J, SEVIOUR T, MARSILI E AND LAURO FM. 2016.
Global transcriptomic responses of Escherichia col K-12 to volatile organic compounds. Sci Rep. 6.

ZENGIN G, AUMEERUDDY-ELALFI Z, MOLLICA A, YILMAZ MA AND MAHOMOODALLY MF. 2018. In vitro and in silico perspectives on iological and phytochemical profile of three halophyte species - A source of innovative phytopharmaceuticals from nature. Phytomed 38: 35-44.

ZHAO H, LIU Q, WANG S, DAI F, CHENG X, CHEN W, ZHANG M AND CHEN D. 2017. In vitro additive antitumor effects of Dimethoxycurcumin and 5-fluorouracil in colon cancer cells. Cancer Med 6(7): 1698-1706. 